\title{
Sistem Pendukung Keputusan Penentuan Berita Hoax Dengan Menggunakan Logika Fuzzy
}

\author{
Christina Aritonang ${ }^{1 *}$, Murni Marbun ${ }^{2}$ \\ ${ }^{1,2}$ STMIK Pelita Nusantara \\ Jl. Iskandar Muda No. 1 Medan 20154 Indonesia \\ Corresponding author's e-mail: christinaaritonang23@gmail.com
}

\begin{abstract}
Abstrak - Media sosial menjadi salah satu keberagaman informasi yang ditawarkan dan keleluasaan dalam membentuk koneksi pertemanan. Setiap orang memiliki kebebasan dalam beropini dalam lingkup sedunia. Banyaknya oknum yang tidak bertanggung jawab untuk membagikan berita hoax dengan maksud memprovokasi pihak lawannya. Penelitian ini adalah pendukung keputusan penentuan berita hoax menentukan berita hoax dengan menerapkan Logika Fuzzy metode mamdani menggunakan bahasa pemograman yang digunakan dalam pembuatan Aplikasi adalah Web, Database dan MySql. Kriteria pendukung keputusan penentuan berita hoax Penyebaran, Literasi Media, Signifikan dan Kepastian. Maka dapat disimpulkan bahwa tingkat Berita hoax tersebut berada pada angka 11.824 atau dikategorikan sebagai SEDANG
\end{abstract}

Kata kunci: berita hoax, kriteria, SPK, Logika Fuzzy

Abstract - Social media is one of the diversity of information offered and flexibility in forming friendship connections. Everyone has freedom of opinion on a worldwide basis. The number of people who are not responsible for sharing hoax news with the intention of provoking their opponents. This study supports the decision to determine hoax news and determines hoax news by applying the Fuzzy Logic of the mamdani method using the programming language used in making applications, namely Web, Database and MySql. The criteria supporting the decision to determine hoax news are Spread, Media Literacy, Significance and Certainty. So it can be concluded that the hoax news level is at 11,824 or is categorized as MEDIUM Keywords: hoax news, criteria, DSS, Fuzzy Logic

\section{Pendahuluan}

Media sosial adalah media paling efektif dalam penerimaan dan penyebaran informasi Hoax. Media sosial menjadi salah satu keberagaman informasi yang ditawarkan,keleluasaan dalam membentuk koneksi pertemanan. Kebebasan dalam beropini dalam lingkup sedunia menjadikan terpaan media semakin besar karena setiap orang memiliki kepentingan masing-masing. Hal semacam ini yang kemudian dimanfaatkan oleh sejumlah oknum tidak bertanggung jawab untuk membagikan berita hoax atau berita bohong dengan maksud memprovokasi pihak lawannya, sedangkan masyarakat internet (netizen) cenderung meneruskan kembali atau mengomentari segala informasi yang mereka minati tanpa berpikir panjang, sehingga berita hoax tersebut viral dan si pembuat berita hoax meraup keuntungan. Berita hoax merupakan suatu pemberitaan palsu atau pemberitahuan yang tidak jelas sumbernya dan biasanya isinya tidak benar. Berita hoax merupakan suatu usaha untuk menipu pembaca untuk mempercayai sesuatu tujuan tertentu, padahal yang membuat berita palsu tersebut mengetahui bahwa berita tersebut adalah palsu. Umumnya hoax bertujuan untuk having fung atau humor. Tetapi, hoax juga dapat digunakan sebagai alat propaganda untuk tujuan politis. Hoax dapat dengan cepat tumbuh dan berkembang seiring dengan popularitas media sosial [1].

Logika fuzzy salah satu pendukung keputusan yang dapat mempresentasikan setiap keadaan atau mewakili pemikiran manusia. Logika fuzzy merupakan jenis logika yang memiliki nilai samar antara benar dan salah. Dalam logika fuzzy, suatu hal bisa bernilai besar dan salah bersamaan[2]. Dalam penerapannya, berkaitan dengan masalah yang mengandung unsur ketidakpastian, ketidaktepatan, ataupun kekaburan. Logika fuzzy banyak diterapkan dalam perangkat-perangkat elektronik seperti air conditioner (AC), mesin cuci. Untuk melakukan pemecahan masalah dengan logika fuzzy, maka ada beberapa metode yang bisa digunakan salah satunya adalah metode Fuzzy Mamdani [3]. Metode Fuzzy Mamdani merupakan salah satu bagian dari Fuzzy Inference Sistem yang berguna untuk penarikan kesimpulan atau suatu keputusan terbaik dalam permasalahan yang tidak pasti. Metode Fuzzy Mamdani dalam prosesnya menggunakan kaidah-kaidah linguistik dan memiliki algoritma Fuzzy yang dapat dianalisis secara matematika sehingga lebih mudah dipahami [4]. Dalam penerapannya metode fuzzy mamdani memberikan kesimpulan yang paling mudah dimengerti manusia seperti pada pendukung keputusan penentuan berita hoax. Penelitian Pendukung Keputusan Pemilihan Tenaga Kontrak Melalui Pendekatan Fuzzy Inference Sistem dengan Metode Tsukamoto (Studi Kasus PT. Solo Murni) 
menjelasakan Penilaian pegawai lepas dilakukan selama sebulan sekali, akan tetapi penentuan pemilihan pegawai kontrak diadakan selama 6 bulan sekali dengan kriteria penilaian presensi, kedisiplinan, kinerja, dan kepekaan [5].

\section{Tinjauan Pustaka}

2.1. Pendukung Keputusan (SPK)

Pendukung Keputusan biasanya dibangun untuk mendukung solusi atau suatu masalah atau untuk mengevaluasi suatu peluang [6]. Pendukung Keputusan tidak dimaksukan untuk mengotomatisasikan pengambilan keputusan, tetapi memberikan perangkat interaktif yang memungkinkan pengambilan keputusan untuk melakukan berbagai analisis menggunakan model-model yang tersedia [7].

\subsection{Logika Fuzzy}

Dasar logika fuzzy adalah teori himpunan fuzzy. Pada teori himpunan fuzzy, peranan derajat keanggotaan sebagai penentu keberadaan elemen dalam suatu himpunan sangatlah penting. Nilai keanggotaan atau derajat keanggotaan atau membership function menjadi ciri utama dari penalaran dengan logika fuzzy [8]. Pada himpunan tegas (crisp), nilai keanggotaansuatu item x dalam suatu himpunan A, yang sering ditulis dengan $\mu \_$A (x), memiliki dua kemungkinan yaitu Satu (1), yang berarti bahwa suatu item menjadi anggota dalam suatu himpunan, Nol (0), yang berarti bahwa suatu item tidak menjadi anggota dalam suatu himpunan [9]. Fungsi Keanggotaan (Membership Function) adalah suatu kurva yang menunjukkan pemetaan titik-titik input data ke dalam nilai keanggotaanya (seiring juga disebut dengan derajat keanggotaannya) memiliki interval antara 0-1 [10]. Salah satu cara yang dapat digunakan untuk mendapatkan nilai keanggotaan adalah dengan melakukan pendekatan [11].

\section{Metode Penelitian}

Tahap dalam penelitian adalah sebagai berikut:

a. Indentifikasi Masalah

Tahapan identifikasi masalah dilakukan untuk mempelajari permasalahan dalam penentuan berita hoax. mengamati penelitian penentuan berita hoax dimana penentuan yang dilakukan masih manual dan hasil yang diperoleh tidak efektif sehingga membutuhkan suatu komputerisasi untuk memprediksi tingkat kebenaran penentuan berita hoax yang dilakukan selanjutnya didalam lingkungan masyarakat agar memberikan hasil yang lebih efektif dan mendapatkan kepuasan bagi setiap individu. Menganalisa masalah, tahapan ini perlu dilakukan untuk mengamati penelitian penentuan berita hoax dimana penentuan yang dilakukan masih secara manual dan hasil yang diperoleh tidak efektif.

b. Pengumpulan Data

Dalam pelaksanaan penelitian ini dibutuhkan dua jenis data yaitu Data Primer, mengumpulkannya secara langsung, dan Data Sekunder, diperoleh atau dikumpulkan dari berbagai sumber

c. Penerapan Metode

Pada proses penerapan algoritma, peneliti melakukan analisis kebutuhan yang akan dikembangkan.

d. Analisa dan Perancangan

Perangkat lunak sangat penting dalam membangun sebuah sistem. Dengan perangkat lunak pengolahan data dapat dilakukan dengan cepat dan akurat. Pada perangkat keras ada banyak program yang bisa digunakan berdasarkan dengan kebutuhan. Kebutuhan perangkat lunak rekomendasi untuk membangun sistem mengidentifikasi tingkat penentuan berita hoax terhadap masyaraka, penulisan kode program menggunakan Php, Database MySql dan Wampserver.

e. Impelementasi

Tahapan membangun sistem sesuai dengan rancangan.

\section{Hasil dan Pembahasan}

Data yang digunakan adalah jumlah berita dalam waktu selama bulan januari sampai Maret. Setelah melakukan proses analisis kebutuhan sistem, maka analisis selanjutnya adalah analisis kebutuhan data. Analisis ini bertujuan untuk memudahkan dalam perancangan informasi. untuk analisis kebutuhan data yang diperlukan antara lain berita dan sumber berita, atribut ini sangatlah mendukung terhadap perancangan aplikasi penentuan berita hoax. Kode Kriteria Berita antara lain C1: Penyebaran merupakan Penyebaran pesan yang berisi fakta(data yang sesuai dengan kenyataan) sehingga menimbulkan penjelasan yang benar dan jelas serta menumbuhkan pengertian yang sama mengenai pesan yang disebarkan. C2: Literasi Media merupakan kemampuan untuk memahami, menganalisis, mendekonstruksi pencitraan media. C3: Signifikan merupakan 
sesuatu yang dianggap penting atau berarti Karena dapat memberikan pengaruh atau dampak, dan tidak bisa lepas dari suatu persoalan. C4: Kepastian merupakan perihal(keadaan) pasti,ketentuan, ketetapan. Penentuan tingkat penentuan berita hoax terhadap masyarakat ditentukan variabel input dan output, Tabel 1.

Tabel 1. Himpunan Fuzzy

\begin{tabular}{|c|c|c|c|c|}
\hline Fungsi & Variabel & Himpunan & Semesta & Domain \\
\hline \multirow[t]{9}{*}{ Input } & Penyebaran & Cukup & {$[0-20]$} & {$\left[\begin{array}{lll}0 & 5 & 10\end{array}\right]$} \\
\hline & & Banyak & {$[0-20]$} & {$\left[\begin{array}{lll}5 & 10 & 15\end{array}\right]$} \\
\hline & & Sangat Banyak & {$[0-20]$} & {$\left[\begin{array}{lll}10 & 15 & 20\end{array}\right]$} \\
\hline & Literasi Media & Tidak Mampu & {$[0-20]$} & {$\left[\begin{array}{lll}0 & 5 & 10\end{array}\right]$} \\
\hline & & Mampu & {$[0-20]$} & {$\left[\begin{array}{lll}5 & 10 & 15\end{array}\right]$} \\
\hline & & Sangat Mampu & {$[0-20]$} & {$\left[\begin{array}{llll}10 & 15 & 20\end{array}\right]$} \\
\hline & Signifikan & Tidak Penting & {$[0-20]$} & {$\left[\begin{array}{lll}0 & 5 & 10\end{array}\right]$} \\
\hline & & Penting & {$[0-20]$} & {$\left[\begin{array}{lll}5 & 10 & 15\end{array}\right]$} \\
\hline & & Sangat Penting & {$[0-20]$} & {$\left[\begin{array}{llll}10 & 15 & 20\end{array}\right]$} \\
\hline \multirow[t]{3}{*}{ Output } & Kepastian & Rendah & {$[0-20]$} & {$\left[\begin{array}{lll}0 & 5 & 10\end{array}\right]$} \\
\hline & & Sedang & {$[0-20]$} & {$\left[\begin{array}{lll}5 & 10 & 15\end{array}\right]$} \\
\hline & & Tinggi & {$[0-20]$} & {$\left[\begin{array}{llll}10 & 15 & 20\end{array}\right]$} \\
\hline
\end{tabular}

Berdasarkan variabel dan domain himpunan yang telah ditentukan, maka langkah selanjutnya adalah menentukan fungsi keanggotaan untuk masing-masing variabel dan menghitung nilai atau derajat keangotaan berdasarkan fungsi keanggotaan yang telah ditentukan.

1. Himpunan Fuzzy Variabel Penyebaran. Variabel penyebaran merupakan memiliki 3 himpunan yaitu Cukup, Banyak, Sangat Banyak.

2. Himpunan Fuzzy Variabel Literasi Media. Variabel Literasi Media merupakan kemampuan untuk memahami , menganalisis, mendekonstruksi pencitraan media. Literasi Media memiliki 3 himpunan yaitu Tidak Mampu, Mampu, Sangat Mampu.

3. Himpunan Fuzzy Variabel Kepastian. Variabel Kepastian memiliki 3 himpunan yaitu Rendah, Sedang, Tinggi.

4. Aplikasi Fungsi Implikasi

Pada perhitungan fuzzy yang diimplementasikan pada penelitian penentuan tingkat penenuanberita hoax pada masyarakat adalah fungsi MIN dan operator AND dengan mengambil tingkat keanggotaan yang terkecil dari variabel masukan sebagai hasil keluarannya. Berdasarkan hasil himpunan variabel studi kasus aturan-aturan yang sesuai dengan kondisi tersebut, maka diperoleh aturan - aturan yang berkesesuaian sebagai berikut:

R1: If Penyebaran Banyak And Literasi Media Mampu And Signifikan Sangat Penting Then Kepastian Tinggi R2: If Penyebaran Cukup And Literasi Media Tidak Mampu And Signifikan Tidak Penting Then Kepastian Rendah

R3: If Penyebaran Cukup And Literasi Media Tidak Mampu And Signifikan Penting Then Kepastian Sedang R4: If Penyebaran Cukup And Literasi Media Tidak Mampu And Signifikan Sangat Penting Then Kepastian Sedang

R5: If Penyebaran Cukup And Literasi Media Tidak Mampu And Signifikan Sangat Penting Then Kepastian Sedang

R6: If Penyebaran Sangat Banyak And Literasi Media Sangat Mampu And Signifikan Sangat Penting Then Kepastian Tinggi

R7: If Penyebaran Banyak And Literasi Media Mampu And Signifikan Tidak Penting Then Kepastian Sedang R8: If Penyebaran Banyak And Literasi Media Mampu And Signifikan Sangat Penting Then Kepastian Tinggi Tahapan Mesin Inferensi, Dilakukan fungsi Min untuk setiap aturan pada fungsi implikasinya

[R1] If Penyebaran Banyak And Literasi Media Mampu And Signifikan Sangat Penting Then Kepastian Tinggi apredikat $\quad=\mu \mathrm{PB} \cap \mu \mathrm{LMM} \cap \mu \mathrm{SSP} \cap \mu \mathrm{KT}=\operatorname{Min} \mu(10,8,16,15)=\min (1 ; 0.6 ; 0.2 ; 0)=0$

[R2] If Penyebaran Cukup And Literasi Media Mampu And Signifikan Tidak Penting Then Kepastian Rendah apredikat $\quad=\mu \mathrm{PC} \cap \mu \mathrm{LMM} \cap \mu \mathrm{STP} \cap \mu \mathrm{KR}=\operatorname{Min} \mu(5,5,3,5)=\min (1 ; 0 ; 0.4 ; 0)=0$

[R3] If Penyebaran Cukup And Literasi Media Tidak Mampu And Signifikan Penting Then Kepastian Sedang apredikat $=\mu \mathrm{PC} \cap \mu \mathrm{LMTM} \cap \mu \mathrm{SP} \cap \mu \mathrm{KS}=\operatorname{Min} \mu(6,5,10,12)=\min (0.8 ; 0 ; 1 ; 0.6)=0$

[R4] If Penyebaran Cukup And Literasi Media Tidak Mampu And Signifikan Sangat Penting Then Kepastian Sedang 
apredikat $\quad=\mu \mathrm{PC} \cap \mu \mathrm{LMTM} \cap \mu \mathrm{SSP} \cap \mu \mathrm{KS}=\operatorname{Min} \mu(6,4,18,12)=\min (0.8 ; 0.2 ; 0.6 ; 0.6)=0.2$

[R5] If Penyebaran Cukup And Literasi Media Tidak Mampu And Signifikan Sangat Penting Then Kepastian Sedang

apredikat $\quad=\mu \mathrm{PC} \cap \mu \mathrm{LMTM} \cap \mu \mathrm{SSP} \cap \mu \mathrm{KS}=\operatorname{Min} \mu(6,5,20,14)=\min (0.8 ; 0 ; 1 ; 0.2)=0$

[R6] If Penyebaran Sangat Banyak And Literasi Media Sangat Mampu And Signifikan Sangat Penting Then Kepastian Tinggi

apredikat $\quad=\mu \mathrm{PSB} \cap \mu \operatorname{LMSM} \cap \mu \mathrm{SSP} \cap \mu \mathrm{KT}=\operatorname{Min} \mu(18,15,20,17)=\min (0.6 ; 1 ; 1 ; 0.4)=0.4$

[R7] If Penyebaran Banyak And Literasi Media Mampu And Signifikan Tidak Penting Then Kepastian Sedang apredikat $=\mu \mathrm{PB} \cap \mu \mathrm{LMM} \cap \mu \mathrm{STP} \cap \mu \mathrm{KS}=\operatorname{Min} \mu(11,9,5,11) \quad=\min (0.8 ; 0.8 ; 0 ; 0.8)=0$

[R8] If Penyebaran Banyak And Literasi Media Mampu And Signifikan Sangat Penting Then Kepastian Tinggi apredikat $=\mu \mathrm{PB} \cap \mu \mathrm{LMM} \cap \mu \mathrm{SSP} \cap \mu \mathrm{KT}=\operatorname{Min} \mu(12,10,15,19)=\min (0.6 ; 1 ; 0 ; 0.8)=0$

Komposisi Aturan (Agregation), Komposisi aturan menggunakan max merupakan kesimpulan secara keseluruhan dengan mengambil tingkat keanggotaan maksimum dari tiap konsekuen aplikasi fungsi implikasi dan menggabungkan dari semua kesimpulan masing-masing aturan,

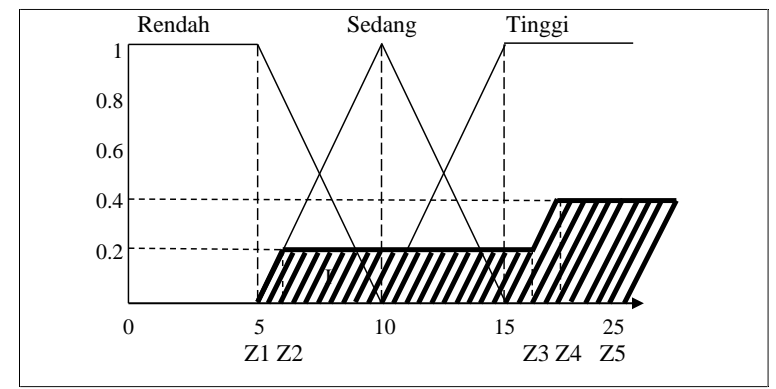

Gambar 1. Komposisi Aturan

Berdasarkan gambar komposisi aturan diatas, maka daerah hasil komposisi terbagi menjadi 2 (dua) yaitu : A1 dan A2. Sekarang kita mencari nilai a1yaitu :

$(\mathrm{z} 1-) /=0,2 \rightarrow \mathrm{z} 1=5 \cdot \mathrm{m} 1=0.2 .(\mathrm{z} 2-5) / 5=0,2 \rightarrow \mathrm{z} 2=6 . \mathrm{m} 2=0.4$

$(\mathrm{z} 3-15) / 5=0.2 \rightarrow \mathrm{z} 3=16 .(\mathrm{z} 4-15) / 5=0.4 \rightarrow \mathrm{z} 4=17$. $(\mathrm{z} 5-15) / 5=1 \rightarrow \mathrm{z} 5=25$

Penegasan (Defuzzyfikasi), metode penegasan yang digunakan adalah metode centroid. Maka, yang pertama adalah menghitung momen setiap daerah.

$Z=\frac{\int_{5}^{6} \frac{Z-5}{5} \cdot z+\int_{6}^{16} 0.2 \cdot z+\int_{16}^{17} \frac{z-15}{5} \cdot z+\int_{17}^{25} 1 . z}{\int_{5}^{6 z-5} \frac{z}{5}+\int_{6}^{16} 0.2+\int_{16}^{17 z-15} \frac{25}{5}+\int_{17}^{25} 1} Z=\frac{0.1328+2+0.1334+168}{1.1+2+3.3+8}=\frac{170.2662}{14.4}=11.824$

Tampilan sistem :

a. Form Halaman Berita merupakan form untuk melakukan proses penginputan data. Pada halaman ini terdapat menu daftar berita dan ada menu tambah berita, refresh,cari berita.

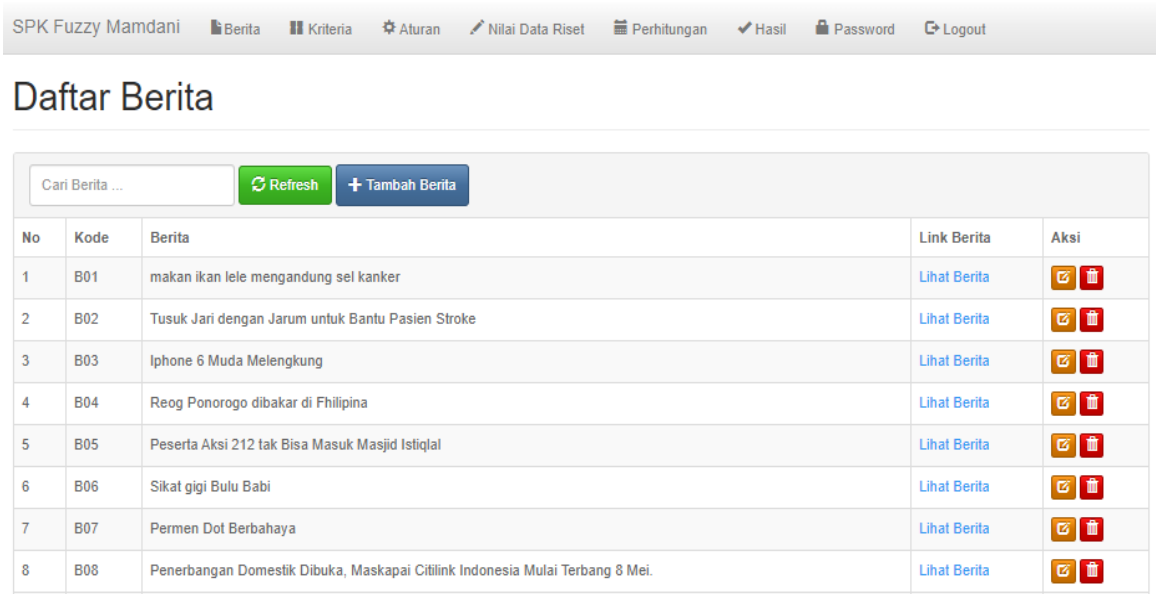

Gambar 2. Halaman Daftar Berita

b. Pada tampilan tambah aturan ada 2 tombol yang digunakan untuk menyimpan aturan yang telah ditambahkan dan tombol kembali, dan disini juga ada tampilan aturan disini kita bisa menghapus aturan 
yang sudah tersimpan.

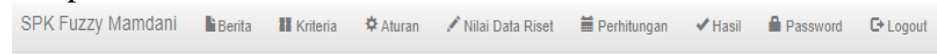

\section{Aturan Fuzzy}
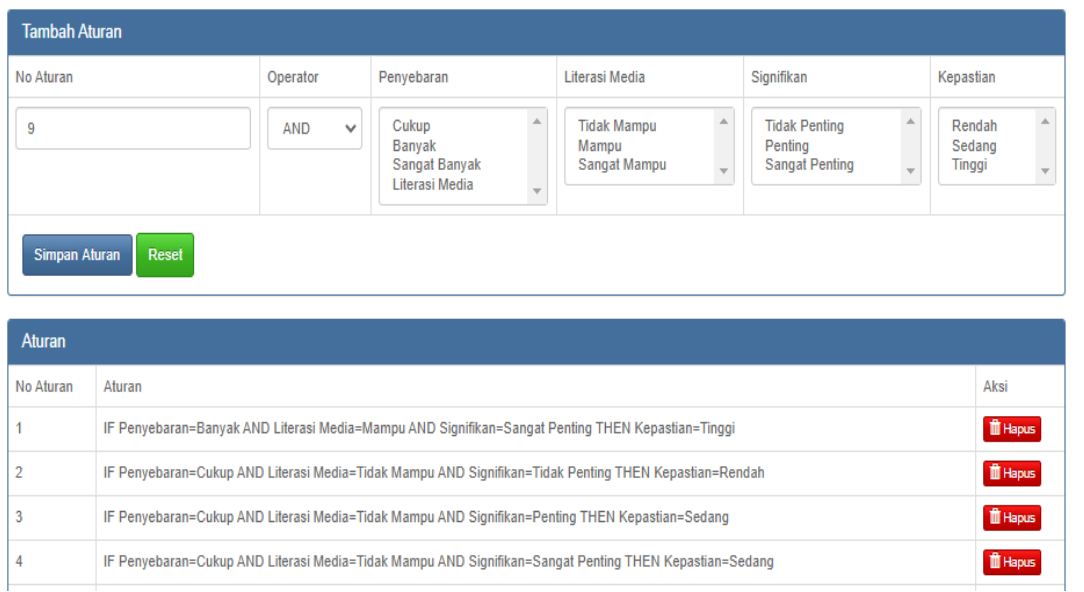

Gambar 3. Halaman Aturan

c. Tampilan Proses Fuzzy Mamdani

Pada tampilan ini ada menu Nilai Berita, Nilai Fuzzifikasi,Implikasi dan Hasil Fuzzyfikasi.

\begin{tabular}{|c|c|c|c|c|c|}
\hline \multicolumn{6}{|c|}{ Nilai Berita } \\
\hline Kode & Berita & & c01 & $\mathrm{C02}$ & $\mathrm{co3}$ \\
\hline 801 & makan ikan lele mengandung sel kanker & & 10 & 8 & 16 \\
\hline 802 & Tusuk Jari dengan Jarum untuk Bantu Pasien Stroke & & 5 & 5 & 3 \\
\hline 803 & Iphone 6 Muda Melengkung & & 6 & 5 & 10 \\
\hline 804 & Reog Ponorogo dibakar di Fhilipina & & 6 & 4 & 18 \\
\hline 805 & Peserta Aksi 212 tak Bisa Masuk Masjjd Istiqlal & & 6 & 5 & 20 \\
\hline 806 & Sikat gigi Bulu Babi & & 18 & 15 & 20 \\
\hline 807 & Permen Dot Berbahaya & & 11 & 9 & 5 \\
\hline 808 & Penerbangan Domestik Dibuka, Maskapai Citilink Indonesia Mulai Terbang 8 Mei. & & 12 & 10 & 15 \\
\hline 809 & Pelemparan Al-Qur'an di Mako Brimob & & 7 & 5 & 10 \\
\hline 810 & CTO Traveloka Wakk Out Saat Gubernur Anies Pidato & & 12 & 8 & 18 \\
\hline 811 & Kronologi 4 Kematian ABK Indonesiadi Kapal Ikan China Menurut Menlu. & & 6 & 3 & 12 \\
\hline 812 & Pemilik Rekening BRI Dapat Transfer an Rp 600.000 & & 6 & 4 & 10 \\
\hline 813 & Pemerintah siapkan RPP Baru.gaji presiden diatas Rp:500Juta & & 11 & 8 & 10 \\
\hline
\end{tabular}

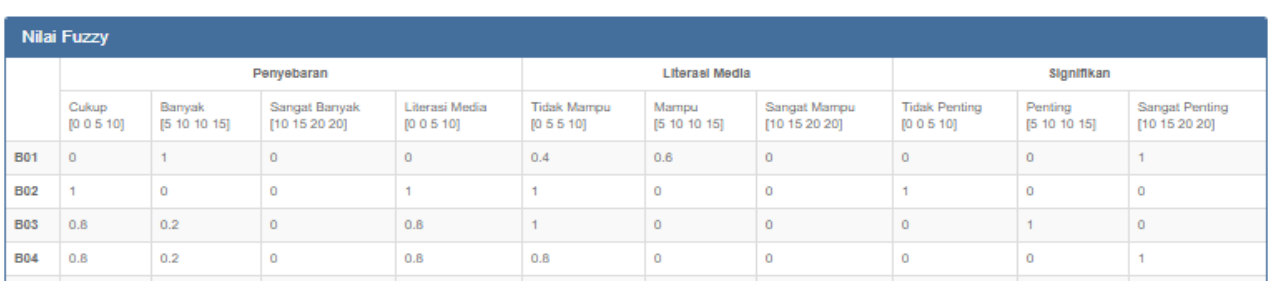

Gambar 4. Tampilan Proses Fuzzy Mamdani

\section{Kesimpulan}

Kesimpulan dari penelitian :

1. Sistem pendukung keputusan penentuan berita hoax menggunakan metode Mamdani terkomputerisasi dan pengujian hasil penentuan berita hoax akan lebih mudah dapat diketahui dan membantu pihak staff kominfo dalam meyelesaikan tugas secara efektif dan efesien.

2. Metode Mamdani dapat membantu menyelesaikan masalah untuk penentuan berita hoax

\section{Daftar Pustaka}

[1] Arman and Defiariany, "Sistem Pendukung Keputusan Dengan Metode Fuzzy Logic Untuk Menseleksi 
Mahasiswa Penerima Beasiswa,” Edik Inform., vol. 02, no. 1, pp. 45-52, 2010.

[2] A. Yaqin, "Sistem Pendukung Keputusan Kelayakan Pemberian Bidikmisi Dengan Fuzzy Logic (Studi Kasus Stmik Amikom Yogyakarta)," CogITo Smart J., vol. 2, no. 1, p. 42, 2016, doi: 10.31154/cogito.v2i1.13.42-53.

[3] H. Sutisna and N. C. Basjaruddin, "Sistem Pendukung Keputusan Pemilihan Pekerjaan Menggunakan Metode Fuzzy Mamdani Studi Kasus: Amik Bsi Tasikmalaya,” J. Inform., vol. 2, no. 2, 2016, doi: 10.31311/ji.v2i2.109.

[4] S. Kasus, D. I. Kecamatan, and B. Sundi, "Logika Fuzzy Dalam Sistem Pendukung Raskin,” vol. 3, no. 1, pp. 93-104, 2016.

[5] Y. H. Siregar, "Sistem Pendukung Keputusan Data Alumni Sarjana," vol. 1, pp. 28-36, 2017.

[6] P. Marpaung, A. Sitio, and A. Sindar, "Optimasi Asupan GGL Ideal Pada Usia Produktif Dengan Algoritma Genetika.” Indonesian Journal of Applied Informatics. Vol. 4 no. 2, pp. 145-151, 2020.

[7] P. Meilina, N. Rosanti, and N. Astryani, "Sistem Pendukung Keputusan Penetuan Jumlah Produksi Barang Dengan Metode Fuzzy Tsukamoto Berbasis Android," J. Univ. Muhammadiyah Jakarta, no. November, pp. 1-2, 2017.

[8] S. R. Andani, S. Wibowo, R. Utara, and C. Catur, "Sistem pendukung keputusan dalam menentukan penerima beasiswa dengan fuzzy sugeno," Techsi, vol. 10, p. 63, 2018.

[9] N. Chaniago and A. Sindar, "SPK Penilaian Hasil Belajar Siswa Menggunakan Metode TOPSIS," vol. 9, pp. 41-48, 2020.

[10] A. Sindar, M. Sitorus, "Machine Learning Prediksi Karakter Pengguna Hastag (\#) Bahasa Generasi Milenial Di Sosial Media,” Indonesian Journal of Applied Informatics. Vol. 4 no. 2, pp. 165-171, 2020. [Online]. Available: https://jurnal.uns.ac.id/ijai/article/view/41764.

[11] F. Indra Sanjaya and D. Heksaputra, "Sistem Pendukung Keputusan Pemilihan Tenaga Kontrak Melalui Pendekatan Fuzzy Inference System dengan Metode Tsukamoto (Studi Kasus PT. Solo Murni)," Semin. Nas. Apl. Teknol. Inf., pp. 1907-5022, 2016. 